\section{International Scientific Journal Theoretical \& Applied Science}

\author{
p-ISSN: 2308-4944 (print) e-ISSN: 2409-0085 (online) \\ Year: $2016 \quad$ Issue: 1 Volume: 33 \\ Published: $30.01 .2016 \quad$ http://T-Science.org
}

Gulchexra Rustamovna Raxmatkariyeva doctoral candidate-researcher of State institute of arts and culture of Uzbekistan grahmatkarieva@gmail.com

SECTION 16. Music. Cinema art. Theatre.

\title{
ABOUT THE SPECIFICS OF THE SMALL SCREEN: AN UNFINISHED DIALOGUE
}

Abstract: In this article we are talking about the specifics of television from the point of view of what the field of artistic creation, production, technical or journalism it belongs to.

Key words: TV, small screen, telecommunication, TV journalism, synchresis, specifics, means of expression, TV production.

Language: Russian

Citation: Raxmatkariyeva GR (2016) ABOUT THE SPECIFICS OF THE SMALL SCREEN: AN UNFINISHED DIALOGUE. ISJ Theoretical \& Applied Science, 01 (33): 154-157.

Soi: http://s-o-i.org/1.1/TAS-01-33-27 Doi: crossef http://dx.doi.org/10.15863/TAS.2016.01.33.27

\section{О СПЕЦИФИКЕ МАЛОГО ЭКРАНА: НЕЗАКОНЧЕННЫЙ ДИАЛОГ}

Аннотация: В настоящей статье речь идет о специифике телевидения, о том, к какой сфере художественного творчества, производства, техники или журналистики оно принадлежит.

Ключевые слова: телевидение, малый экран, телекоммуникация, тележурналистика, синкрез, специифика, средства выразительности, телепроизводство.

Существуют разные ответы на вопросы о том, к какой сфере художественного творчества, производственной деятельности телевидение относится - к искусству или журналистике, художественной культуре в целом или к техническим средствам передачи (в том числе эстафетной) информации; каковы его природа, структура, компоненты, функции и т.д.

В искусствоведческих работах телевидение ставится в один ряд (по линии природных, эстетических свойств, восприятия коммуникативных характеристик, технологий) с основными (традиционными) видами искусства. Отдельные авторы причисляют его к «малоэкранному кино» или, напротив, видят кино в контексте ТВ.

Если искусствоведы, философы склонны рассматривать телевидение как часть обширной художественной сферы, то журналистиковеды разных научных школ относят его к журналистике (наряду с журнально-газетной и радийной). Ряд исследователей неизменно связывают ТВ (как систему телевещания с разнообразными видами телевизионной деятельности внутри нее, включая и журналистскую) с тележурналистикой в рамках СМИ, отказывая ему в самостоятельности.

Однако подобные утверждения без учета специфики этого явления за пределами собственно журналистики, выступающей в эфирном пространстве одной из его составляющих, вряд ли имеют под собой твердой почвы. Тем более, когда XXI век - век техногенной цивилизации вносит свои коррективы в структуру, формы и содержание телеэкрана и требует всестороннего охвата и осмысления проблемы.

Далеко не все концепции выдержали испытание временем. Сфокусированные на одном из компонентов телевизионной деятельности, одни незаметно сошли со сцены, другие продолжают взывать к острым дискуссиям о самостоятельности, самоценности или прикладном значении ТВ, его месте в системе искусства, средств массовой информации, журналистики как таковой или же креативных формах технического производства.

В характеристике сущности телевидения В.Ю.Борев и А.В.Коваленко апеллируют к искусству и журналистике одновременно [2]. 
Г.В.Кузнецов [4], В.Л.Цвик [10], А.Я.Юровский [11] видят в нем публицистичность, художественность и научность. Потому ряд исследователей говорят о многослойности ТВ, о необходимости системного подхода к его осмыслению, на чем настаивали еще в 80-е годы прошлого века Ю.П.Буданцев [3], О.Ф.Нечай [7], К.Разлогов [8] и что соответствовало представлениям зарубежных ученых, в том числе М.Маклюэна [5], А.Моля [6], Р.Уильямса [9] и др. о мозаичности, многоступенчатости данного явления.

В рамках культурологии ТВ понимается не отдельно как искусство или журналистика, а как зрелище. То есть синкрез (нерасчлененное единство) различных видов деятельности: производящей и презентующей, социальнотворческой, журналистской.

М.М.Бахтин [1] в свою очередь отмечает родство телеэкрана с карнавальным мироощущением, основанным на синкретизме. И это родство заложено в самой природе зрелища и типе коммуникации - игровой, драматической, театральной. И если карнавал является повторяющейся формой жизни, то телевидение буквально «вросло» в повседневность.

Без телеэкрана, который является связующим звеном между реальной и виртуальной жизнью, сегодня не представляется полноценное, социально адаптированное существование человека, остро нуждающегося во всякого рода информации и аналитике, художественно-образных, познавательных и развлекательных формах. Телевидение и есть, по существу, сама жизнь без живого соучастия в действе и общения со средой, открывающая столь необходимые для человека коммуникационные модели.

И здесь речь должна идти не только о качестве вещания и понимании специфики телевидения на новом витке развития массовых коммуникаций, но и о культуре потребления, чему тоже учит телевидение. Как синкрез разных форм деятельности, о чем говорилось выше, оно примечательно также сочетанием в себе одновременно полномочий печати, радио, экранного искусства и техники. По скорости отражения жизненных событий (новости, трансляции, прямые репортажи), по охвату пространства и времени, бесперебойности передач, креативности технических, профессиональных решений, мобильности передвижения ему на сегодня нет равных ни среди традиционных искусств, ни печатной сферы.

Можно говорить о зрелищности телевидения, жадно вобравшего в себя выразительные средства традиционных искусств (театра, кино, музыки, изобразительного искусства, архитектуры и др.) и умело использующего разнообразный художественнообразный арсенал; можно говорить и о его синтетической природе, проявляемой:

- во внешней структуре, соединившей искусство, технику и СМИ;

- в программной деятельности, неотъемлемой частью которой являются различные виды литературы и искусства (современного, традиционного, академического, народного, профессионального);

- характере телевизионных произведений, созданных усилиями большой группы людей (авторов, редакторов, режиссеров, операторов, звукооператоров, сценографов, музыкантов, осветителей, монтажеров, специалистов по видео и компьютерной технике);

- новостной и информационноаналитической продукции, состоящей из средств массовой информации и пропаганды, а также телеискусства (наличие драматургии, хроникальных кадров, фотоиллюстрации, музыки, дизайна, монтажа);

- жанровой природе телевизионных произведений (телефильмы, телеспектакли, репортажи, ток-шоу, интервью и др.), представляющей собой разные формы творческой деятельности, разные виды и жанры искусства.

Опора на традиционные жанры, на достижения современной техники и технологии, a также наработанный веками богатый журналистский опыт придают телевидению не только уникальность, но и самостоятельность в сфере искусств.

Понятие «жанр» по отношению к телевидению имеет не только формообразующее значение. Оно несет также смысловую и эмоциональную нагрузку, обеспечивает целостность, конкретность восприятия информационного потока, способствует выявлению закономерностей развития в связи с характером и содержанием социальных противоречий, общественным сознанием и общественной психологией на том или ином отрезке исторического времени.

Как видно из вышесказанного, жанровая идентификация телевидения сводится к отождествлению его с тележурналистикой, искусством, технологическими компонентами, освещению исторического, прогностического аспектов, вне связи с текущей реальностью. Не являясь исключением из общих правил, она мотивируется сложностью, как самой проблемы классификации, так и многозначностью объекта, что делает уязвимыми практически все попытки его структурного осмысления.

Спорность существующих критериев объясняется еще тем, что в их основу кладутся 
порой не характеризующие, а чисто внешние признаки. Тогда как телевидение живет по иным, нежели периодическая печать, радио, а также традиционные искусства законам, требуя к себе соответствующего подхода, который учитывает его комплексную, синтетическую и многоуровневую природу, аккумулирующую журналистику, искусство, современный творческотехнологический и методологический процесс. И в этой схеме свое неизменное место занимает зрительское восприятие в качестве важнейшей составляющей коммуникационного процесса и меры условности, что даёт возможность нащупать новые ориентиры (или основания) для более точной классификации телевидения.

Жанровая определенность телевизионных произведений, имеющая и теоретическое и практическое значение, важна не только с содержательной, но и с технической точки зрения, поскольку от этого зависит технология производства и качество телевизионной продукции, что в свою очередь является свидетельством вовлеченности в современный цивилизационный процесс.

Художественное телевидение сложилось на почве опосредованной преемственности художественных традиций, заимствования и переосмысления готовых произведений, а также создания, в связи с концепцией малого экрана, новых. Постепенно менялись и формы подачи новостей, рекламы, передач, которые приобретали в условиях телекоммуникаций специфически телевизионные качества, одновременно решая задачи нравственноэстетические, мировоззренческие, социализирующие, образовательные.

Жанры телеискусства не стоят на месте. Они объединяются и, набрав необходимый творческий потенциал, отпочковываются, двигаясь своим путем дальше, и потому, вероятно, трудно идентифицируются. Возникают так называемые авторские жанры, создаваемые фактически под конкретную личность и маркируемые конкретным именем. Телевизионный модератор, ведущий радиопрограмм, аналитик газеты по значимости нередко превосходят политических ньюсмейкеров с хорошим рейтингом.

Многоролевая игра и рождение синтетических образований, технологические ухищрения и массмедиа, факты и события, поданные в красочной, игровой и постановочной форме, с обилием графики, заставок и стертых переходов между передачами и программами, явствуют о новомодных тенденциях в раскрытии материала, ставя вновь и вновь задачи переосмысления, дополнения, уточнения системы жанровоклассификационных признаков.
В том случае, когда же речь идет о слиянии разновеликих, традиционных и вновь обретенных форм, жанровая идентификация возможна исключительно на основе определения первостепенных и паритетного значения «базисных» признаков искусства или ряда искусств (телеопера, телемузей, теледизайн, телесветомузыка, телехореопластика).

Развитие телевизионных жанров, детализация структуры и дивергенция вариантов позволяют наглядно демонстрировать богатство изобразительно-выразительного языка ТВ. Если журналистика сближает его с печатными и электронными СМИ, то художественно-творческая деятельность связана с кино, театром и другими видами творческого созидания.

Телевидение использует также и семиотическую систему - знаки, символы, сочетаясь с ними в ненавязчивых последовательностях, путем ассоциативной игры параллелизмов и контраста, создавая мощные, эмоционально активные в зрительском восприятии, инвариантные относительно времени и места, стереотипические и в высокой степени условные образы-мифы и образы-символы, обогащающие содержательный контент вещаемого произведения, пробуждающие воображение и фантазию телеаудитории.

Специфика телевизионных жанров заключается в пространственно -временной организации, которая связана с одновременностью показа и восприятия события. Это то, что называется сиюминутностью, и вне телевидения не представляется возможным в плане жанровой атрибуции. (Например, прямой репортаж или пьеса идут и на радио, но без изображения -видеоряда).

В данном случае понятие «тележанр» близится к понятию «хронотоп», типология которого разработана в литературоведении, но применима к искусству $\mathrm{c}$ текстовой формой творческого продукта, в чем видится связь телевизионной драматургии с филологическими закономерностями. Возникновение, становление новых и отмирание старых, изживших со временем свои ресурсы жанров - процесс исторически неизбежный. Практика убеждает в ограниченности рамок, а порой несостоятельности раз и навсегда данной схемы жанровой идентификации, особенно применительно к вновь образовавшимся явлениям современного искусства.

Потому теория жанров тоже пребывает в состоянии поиска, видоизменяясь вместе с живой и изменчивой художественной реальностью, делая попытки дать ей твердое обоснование.

Что продлевает и развивает успех телевидения, помимо того, насколько верно угаданы (в динамике) его жанровые признаки?

Очевидно, что многое зависит от эффективного использования передовых 
технологий и мирового опыта телекоммуникаций, определения стратегии и тактики функционирования, приоритетных направлений деятельности телевидения, включая его структурные образования, работу творческих служб и подразделений.

Не менее важен здесь сам процесс поисков наиболее перспективных путей, способов и приемов достижения подлинно творческой атмосферы, экономической стабильности, конкурентоспособности, выхода на региональный и мировой информационный рынок.

Актуальными были и остаются поныне такие факторы развития, как укрепление материальнотехнической базы, привлечение инвестиционных средств, оптимизация, интенсификация производства и вещания телепродукции, соответствующей современным требованиям [12], [13].

В числе неотложных задач - стимулирование творческой активности действующего персонала, забота об улучшении условий и качества труда, повышение квалификации специалистов всех рангов и подразделений ТВ.

В условиях глобализации и интеграции в мировое культурное сообщество актуализируются вопросы расширения сфер влияния, налаживания и укрепления производственных контактов в рамках региона, стран сотрудничества и дальнего зарубежья, обогащения национального рынка произведениями традиционного, академического, современного искусства и выхода на широкое коммуникационное пространство.
Особого внимания заслуживают такие вопросы, как разнообразие материала, оригинальность творческой идеи и средств воплощения, профессионализм, креативность творческо-производственной группы. Не менее важны духовно-нравственные, этические, мировоззренческие проблемы, которые воспитывают у молодого зрителя базовые ценности, способность совершенствовать себя и окружающий мир.

Следует сказать и о соблюдении всех условий внутрипроизводственного и вещательного этикета, соответствии всей деятельности ТВ, включая формально-содержательные аспекты программ и передач, высоким профессиональным требованиям.

Примечательность телевидения в том, что оно, в отличие от близких ему сфер творчества, обладает богатыми техническими ресурсами, стремительно распространяющейся спутниковой связью, средствами накопления и вещания информации. Современные технологии создания телевизионной продукции предполагают комплекс организационно-технических (продюсеры), экономических (менеджеры), художественноэстетических задач, главная из которых подготовка и передача материала в эфир.

Потому со всей уверенностью можно говорить о специфике малого экрана, которому присущи свои методы, технологии, своя поэтика и свое назначение в системе универсальных ценностей, где жанровая типология занимает не последнее место.

\section{References:}

1. Baxtin MM (1990) Tvorchestvo Fransua Rable i narodnaya kultura srednevekovya i Renessansa. 2ye izd. Moscow.

2. Borev VY, Kovalenko AV (1986) Kultura i massovaya kommunikatsiya. Moscow.

3. Budansev YP (2001) Osnovii jurnalistskogo obrazovaniya/ Sbornik nauchniikh statey. Moscow.

4. Kuznetsov GV (2002) Televizionnaya jurnalistika. Moscow.

5. Maklyuen M (1987) TV: vchera, segodnya, zavtra. Moscow.

6. Mol A (1973) Sotsiodinamika kulturii/Per. s fr., vstup. st., red. i primech. B.V.Biryukova. Moscow.
7. Nechay OF (1990) Rakursii: o televizionniikh kommunikatsiyakh i estetike. Moscow.

8. Razlogov K (1998) Osobennosti ekrannoy kommunikatsii. Sankt-Peterburg.

9. Uilyams R (1992) Televideniye: texnologiya i kulturnaya forma. Moscow.

10. Svik VL (2004) Televizionnaya jurnalistika: Istoriya, teoriya, praktika: Uchebnoye posobiye. Moscow.

11. Yurovskiy AY (1983) Televideniye: poiski i resheniya. Moscow.

12. (2015) Available: http://www.mtrk.uz (Accessed: 20.01.2016).

13. (2015) Available: http://www.ziyonet.uz (Accessed: 20.01.2016). 